\title{
CONTRIBUTION TO THE KNOWLEDGE OF BUTTERFLY AND MOTH FAUNA (INSECTA: LEPIDOPTERA) OF GORNJE PLAVNICE, BJELOVAR, CROATIA - RESULT OF A ONE YEAR PHOTOGRAPHIC STUDY
}

\author{
Monika Veljković \\ Gornje Plavnice 56, 43000 Bjelovar, Croatia (mv52874@gmail.com)
}

\begin{abstract}
Veljković, M.: Contribution to the knowledge of butterfly and moth fauna (Insecta: Lepidoptera) of Gornje Plavnice, Bjelovar, Croatia - result of a one year photographic study. Nat. Croat., Vol. 28, No. 2., 345-358, Zagreb, 2019.

This paper gives a list of 100 species from 14 families of Lepidoptera found in Gornje Plavnice near Bjelovar, Croatia in the period from 14 April 2017 to 1 September 2017. This photographic research, conducted mainly in meadows, fallow land, forest edges and backyards in the study area, presents a contribution to the knowledge of butterfly and moth fauna of the Bjelovar-Bilogora area as well as of Croatia as a whole.
\end{abstract}

Key words: Lepidoptera, fauna, Gornje Plavnice, Bjelovar-Bilogora area

Veljković, M.: Prilog poznavanju faune danjih i noćnih leptira (Insecta: Lepidoptera) u Gornjim Plavnicama, Bjelovar (Hrvatska) - rezultat jednogodišnjeg fotografskog istraživanja. Nat. Croat., Vol. 28, No. 2., 345-358, Zagreb, 2019.

Rad donosi popis 100 vrsta leptira iz 14 porodica, zabilježenih u Gornjim Plavnicama blizu grada Bjelovara, Hrvatska, od 14. travnja 2017. do 1. rujna 2017. godine. Ovo istraživanje, temeljeno na fotografijama, uglavnom se provodilo na području livada, neobrađenih poljoprivrednih površina, rubova šuma i dvorišta na području istraživanja te predstavlja doprinos poznavanju faune danjih i noćnih leptira Bjelovarsko-bilogorskog područja i Hrvatske.

Ključne riječi: Lepidoptera, fauna, Gornje Plavnice, Bjelovarsko-bilogorsko područje

\section{INTRODUCTION}

One hundred and ninety seven butterfly species have been recorded in Croatia (ŠAšić et al., 2015) but around 3,000 moth (KučInić \& Plavac, 2009). Although more numerous, moths are little represented in the literature in Croatia, while for butterfly fauna there is much more published information, as well as the first checklist of Croatian butterflies (ŠAšić \& MiHocI, 2011) and a Red Book of Butterflies of Croatia (ŠAšić et al., 2015). However, there have been some improvements, through newly published data about moths in Croatia such as the first checklist of the Arctiinae subfamily (Kučınıć et al., 2014), the moth fauna of Motovun forest (Koren et al., 2015), of Lonjsko polje (Koren et al., 2017), the surroundings of the Bednja River, Varaždin County (Koren, 2018). However, for some areas in Croatia, fauna of neither butterflies nor moths is sufficiently studied; one such area is that of in the Bjelovar-Bilogora area, within Bjelovar-Bilogora County. About butterfly fauna there are only a few papers (e.g. GruBišić et al., 2006; Miноci et al., 2007; FIšTREK, 2018), while data about moth fauna in Bjelovar-Bilogora area are scarce. 
High quality digital photographs not only give an opportunity for less invasive research into butterfly diversity, not involving the killing of observed individuals, (Koren \& Letić, 2014) but also enables the study and documentation of an unfamiliar or even rare species a long time after field research (QUINN \& KLYM, 2009). Moreover, according to QUINN \& KLYM (2009), photographs can reveal shapes, patterns and even behavior not noticed during field work. Furthermore, photographs with the correct coordinates, locality name, date and observer, create valuable data (Koren \& Letić, 2014). According to Winterton et al. (2012), due to the sharing of such photographs in online image databases, species new for science have been discovered; the base for their recognition as new for science by professional taxonomists and formal descriptions has been created. In the time of global climate change and rapid biodiversity loss, social media and web platforms about butterflies and moths can be a good base for further research, like eButterfly, a web-platform in North America where butterfly enthusiasts create a globally accessible database of butterfly observations (PrUDic et al., 2017). There are similar web-platforms in different parts of the world (Butterflies of India, Moths and Butterflies of Europe and North Africa, UK Moths, Lepiforum e. V., Leptiri.net (Croatia), Observado, iNaturalist in Europe. However, according to Koren \& Letić (2014), for correct identification, considerable knowledge on the local butterfly fauna is needed as well as butterfly identification guides (LAFranchis, 2004; Tolman \& LeWIngton, 2008). Also, for some species, especially moths, photographs are not enough for correct identification, and genitalia analysis is needed. For instance, in this study some moth families like Gelechiidae and Pterophoridae, in agreement with Dr. Koren, were excluded from the species list because their identification only from photographs and without genitalia analysis would not be reliable. For identification of both butterfly and moth species that cannot be properly identified only from the field observations and digital photographs or for confirmation of correct identification, some methods like genitalia analysis (e.g. Mrnjavčić Vojvoda et al., 2014; KučInić et al., 2014; Koren, 2018, etc.) and, recently, the DNA bar-coding approach (e.g. HajibABAEI et al., 2006; Jin et al., 2018) are used. In some genera, species are very similar, which complicates their determination, as in numerous members of the genus Catocala, where maculation, genitalia and barcodes may not be enough for correct species identification, so study of host plants and larvae also should be conducted (https://mothphotographersgroup.msstate.edu). Still, the majority of butterfly species occurring in Croatia can be correctly identified from the photographs by the entomologists (Koren \& Letić, 2014). Moreover, according to PATterson (2012) a large number of moths can be identified in this way. However, there is no available data about research into moths in Croatia based on the digital photographs.

Usage of digital photography in butterfly and moth research is getting more attention with the development of this technology, so many authors use digital photography together with other methods (e.g. BAsset et al., 2000; Rice \& White, 2015), while others like MedHi et al. (2018) studied butterfly diversity in India 
on the basis of digital photography and observations. Sourakov (2018) utilized digital photographs and observations in research into mass aggregations of Idia moths (Lepidoptera: Erebidae) in Florida. Some authors go further, like ReмвоsкI et al. (2018), with the use of digital image processing and machine learning techniques for identification of fruit flies, or like Suetsugu \& HayAmizu (2014) with the use of interval photography with a digital camera to show moth visitors of the Platanthera orchids. In Croatia there have also been some improvements, at least in using digital photography in butterfly research; KoREN \& LeTić (2014) conducted the first photographic survey of butterfly diversity in Croatia, based on identification from the photographs, while recent studies mostly use photographs in addition to other methods (Koren et al., 2017; FišTrek, 2018).

The aim of this preliminary photographic research project, based on the identification of specimens from photographs taken in the surveyed area, is to make a contribution to the knowledge of the butterfly and moth fauna of this previously under-surveyed area and about possible threats to their biodiversity.

\section{MATERIAL AND METHODS}

\section{Study area}

Bjelovar-Bilogora County has an area of $2.652 \mathrm{~km}^{2}$, which is $3.03 \%$ of the total area of Croatia. The county has a few cities (Bjelovar, Daruvar, Čazma, Garešnica and Grubišno Polje) and a large number of villages and settlements. It is situated in the central part of continental Croatia and has four characteristic geographic units: Bilogora (north and northeast), bordering the mass of Papuk and Ravna Gora (east), Moslavačka gora (southwest) and the valleys of the Česma and Ilova (west, central and south) (http://www.bbz.hr). Bilogora is a low, broad mountain in northern Croatia, which stretches along the southwestern edge of Podravina from the northwest to the southeastern part, in a length of about $80 \mathrm{~km}$. The highest peak is called Stankov vrh $(309 \mathrm{~m})$. The entire surface is covered with a herbal mantle (PoLJAK, 2001). The lower slopes are under vineyards, orchards and corn fields, while above them continue forests, predominantly deciduous. It is part of the lowland oak forests region, with complexes of sessile oak(Quercus petraea (Matt.) Liebl.) and hornbeam (Carpinus betulus L.). Common oak (Quercus robur L.) can also be found there as well as beech, Fagus sylvatica L. on the north slopes (PoljaK, 2001). The study area in this paper comprises the edge parts of the Bilogora and the northern surroundings of the city of Bjelovar. Gornje Plavnice is a village in close vicinity (north side) of the city of Bjelovar, traditionally an agricultural part of Croatia covered with agricultural fields, meadows and deciduous forests, like the most of Bjelovar - Bilogora area. Most of the surveyed area consists of agricultural land covered with crops like corn, wheat, barley, oil seed rape, etc. with only a few fallow parcels. The area is fragmented into many smaller parcels with mentioned crops but also with gardens, meadows, and fallow land near each other. 


\section{Butterfly and moth photographic survey}

The research was performed from 14 April 2017 to 1 September 2017, on an area of $387,000 \mathrm{~m}^{2}$, situated in Gornje Plavnice near Bjelovar, in the continental part of Croatia (see Fig. 1), where specimens of butterflies and moths were observed and photographed. Moths were photographed resting on house walls below the external house light during night. The habitats present in this area include wet and mesophilous meadows, forest edges, glades, agricultural land, fallow land, backyards, orchards and gardens. Butterflies and moths were photographed by the author. Butterflies were identified using Tolman \& Lewington (2008) while identification of moth species was done according to Fibiger (1993), Leraut (2009; 2014), Nowacki (1998), MANLey (2008) and Waring et al. (2003). Also, a professional butterflies and moths website (www.lepiforum.de) was used. Furthermore, identification of both moth and butterfly species was revised by Dr. Toni Koren from the Hyla Association, Zagreb. Systematics follows Van Nieukerken et al. (2011). All collected photographs of butterflies and moths are kept in the author's private collection. Plant species were identified using Doмас (2002) and Niкolić (2018) (Flora Croatica Database).

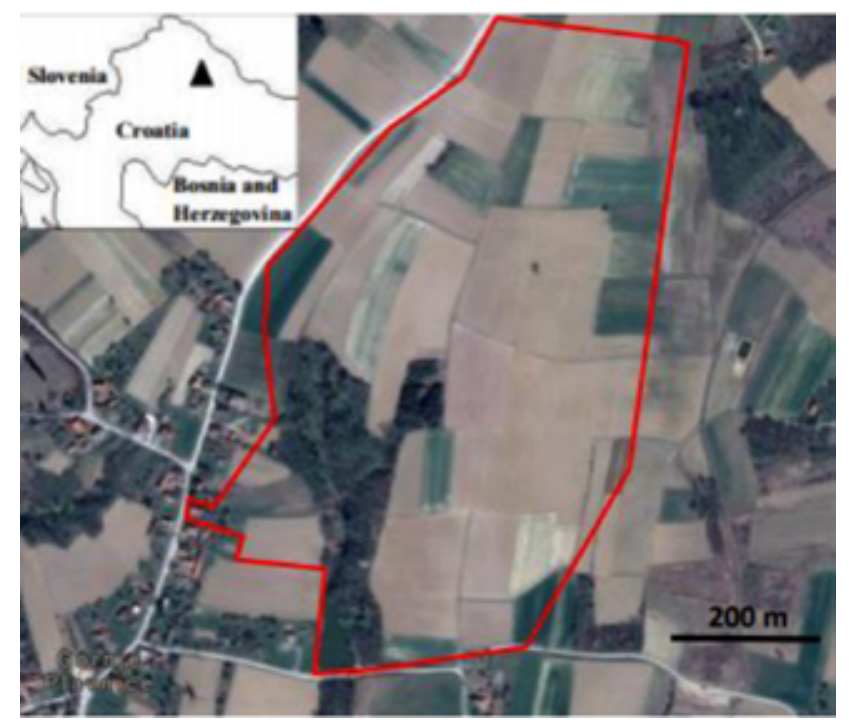

Fig 1. Location of the study area in Gornje Plavnice near Bjelovar, Croatia.

\section{RESULTS AND DISCUSSION}

Although the overall number of photographs taken during the research reached around 3,200, many of them were not enough clear for proper identification. Consequently, on the base of a total number of 2,030 high quality photographs, 100 species from 14 Lepidoptera families were identified. From the whole number, 36 species were butterfly species and three of them are listed in the Red Book of Butterflies of Croatia (Šsšić et al., 2015): Apatura ilia, Lycaena dispar and Papilio machaon as Near Threatened (NT). Most recorded butterfly species belong to the 
families Nymphalidae (16) and Lycaenidae (8). In this research, the most common moths were geometrid moths (Geometridae) with 23 species and noctuid moths (Noctuidae) with 17 species. Species from other families were less found and contained 1-7 species. The list of butterfly and moth species is presented in Tab. 1 .

Usually, meadows in this area are mowed two to three times every year in order to produce hay for livestock feeding and the vegetation mostly consists of species from the family Poaceae and Fabaceae as well as of other plant families like Apiaceae, Asteraceae, Ericaceae, Rubiaceae and Lamiaceae. Most of the surrounding arable fields in the study area are fertilized with mineral fertilizers and treated, a few times during the season, with herbicides and pesticides, which have a bad effect on insects. As the meadows are mainly near such agriculture land, their flora and fauna are also affected by chemicals because of airborne transmission. Meadows occupy a much smaller part of the study area than agricultural land because of agricultural intensification and reduced production of hay for livestock feeding. Furthermore, in July and August 2017, seismic investigation of oil and gas reserves in this area was conducted and many meadows were invaded by heavy machines, whereas on some meadows new boreholes are planned. All these factors could affect butterfly and moth biodiversity as most of them were found on mesophilous and wet meadows (30 of 36 butterfly species and 19 of 64 moth species), but further research about their populations should be conducted. The most frequently found butterfly species on the meadows in the study area were Polyommatus icarus, Coenonympha pamphilus, Pieris rapae and Lycaena phlaeas. The least frequent species are Iphiclides podalirius, Erynnis tages, Pyrgus malvae, Pyrgus armoricanus and Thymelicus sylvestris. Some flower generalist species like P. icarus, C. pamphilus and Maniola jurtina (WALlis DE VRIEs et al., 2012) occurred on the flowers of different plant species. P. icarus was attracted by the flower of Trifolium pratense L., Trifolium repens L. as well as by flowers of Convolvulus arvensis L., Centaurea sp.and Erigeron annuus (L.) Pers. P. icarus, also photographed on its host plant Lotus corniculatus L., according to JANZ et al. (2005) has strategy for host plant searching that allows the usage of the same host plant individual for both oviposition and adult nutrition. Being a favored plant for both adult nutrition and food for larvae, L. corniculatus enables $P$. icarus females to search for only one resource to complete both tasks (JANz et al., 2005). Some flower specialist butterfly species, like a copulating pair of E. tages (WALlis DE VRIEs et al., 2012), occurred near their main larval food plant, Lotus corniculatus L. (Gutiérrez et al., 2001). Furthermore, Cyaniris semiargus, an indicator species of unmanaged sites like abandoned grasslands and Cupido argiades, an indicator species of alluvial meadows (TRAPPE et al., 2017), were photographed on the flower of Trifolium pratense L. Flowers of the plants from the genus Centaurea attracted many butterfly species like T. sylvestris, Lasiommata megera, C. pamphilus, Melitaea athalia, Aglais io, M.jurtina, Melanargia galathea, Araschnia levana, while C. pamphilus and $C$. argiades were found also on the flower and leaf of a plant from the genus Plantago, near a backyard in the study area. One specimen of L. dispar was photographed, on a newly sown meadow, on the leaf of Sorghum halepense 
(L.) Pers. (see Fig. 2). This corresponds to the finding of TrAppe et al. (2017) where L. dispar occurred on seminatural grasslands. The nearest finding of this species in Bjelovar-Bilogora is the finding of $L$. dispar in Grubišnopoljska Bilogora (Minoci et al., 2007). Pieris napi, a species that favors more humid meadows and forested areas (FrIBERG et al., 2015), was attracted by the flower of the Centaurea sp. Flowers of some invasive plant species like Erigeron annuus (L.) Pers. attracted P. armoricanus, C. glycerion, C. pamphilus, L. phlaeas, $M$. jurtina, M. athalia, Neptis sappho, while Issoria lathonia was found on the flower

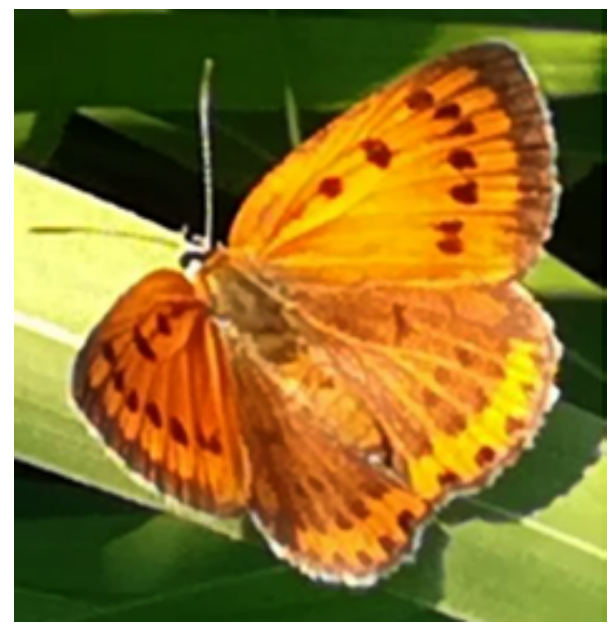

Fig. 2. Lycaena dispar (Haworth, 1802) in the study area near Bjelovar, Croatia. of the Solidago canadensis L.

Moth species like Cydia pomonella, Celypha striana, Oncocera semirubella, Pyrausta purpuralis, Nomophila noctuella, Chiasmia clathrata, Selenia lunularia, Ematurga atomaria, Idaea ochrata, Polypogon tentacularia, Euclidia glyphica, Deltote bankiana, found on the meadows in the study area, mainly appeared on the leaves of the plants from the family Poaceae. Acontia trabealis was photographed on the leaves of Convolvulus arvensis L., A. trabealis the main food plant (Konen et al., 2015), whereas Acontia lucida was found on the flower of the Centaurea sp. Tyta luctuosa was found resting on a leaf of Achillea millefolium L., close to the part inhabited with Convolvulus arvensis L. and species of the genus Plantago, used for the feeding of T. luctuosa caterpillars (Koren \& Gомвоc, 2017). T. luctuosa, according to Rosenthal et al. (1988) and Tóth et al. (2004), has potential value as a biological control agent for $C$. arvensis, which can be potentially useful for reducing the usage of herbicides, used in the study area. E. atomaria was found on the leaves of Trifolium sp., used as food plant for caterpillars of this species (Koren \& Gomboc, 2017) and, like P. tentacularia and Heliothis viriplaca, on the flower of the invasive species Erigeron annuus (L.) Pers. Meadows in the study area are also inhabited by Mentha sp., one of the host plants of Scopula ornata (found near the house light), as well as by plants from the genus Galium, Stellaria and Campanula, host plants of another species of Geometer moths, Xanthorhoe ferrugata, recorded near the house light (Koren et al., 2015).

Fallow land in the study area was mostly agricultural land that had not been cultivated for a few years. Although mostly plants from the family Poaceae inhabit such land, nowadays some invasive alien species such as Ambrosia artemisiifolia $\mathrm{L}$. and Solidago canadensis L. occur there. In parts closer to the wood edge, young trees of Juglans nigra L. and even Robinia pseudoacacia L. occur. A. levana occurred on a flower of Solidago canadensis L. and on a flower of Daucus carota L. ssp. carota, whereas Melitaea phoebe was sitting on the leaf of the host plant Cirsium arvense (L.) Scop., and on a young tree of Juglans nigra L., near the area where another M. phoebe 
host plant, Cirsium vulgare (Savi) Ten. grows (Tótн et al., 2015). N. sapphoand M. athalia occured on the leaf of Ambrosia artemisiifolia L. Mosaic of fallow land and meadows, mown occasionally in the study area, presents an important habitat for the survival of Rhyparia purpurata, a rare species in Croatia (Koren \& Gomboc, 2017). In this study, a specimen of $R$. purpurata was found near the forest edge, on a leaf of Achillea millefolium L. and close to R. purpurata caterpillar food plants from the genus Cirsium, Galium, Rubus and Trifolium (Koren \& Goмвос, 2017).

Although agricultural land has much lower biodiversity, some butterfly and moth species were found there. Aglais io was found sitting on the ground near the edge of the agricultural land covered with Zea mays L. Some part of the study area is under the crop Brassica napus L. Although it demands pesticide and herbicide treatments during the flowering period, this crop attracts insects like bees and butterflies. Pieris rapae was found on the leaf of Urtica dioica L., on the forest edge and on the meadow plant from the genus Lamium, close to a field with oil seed rape (Brassica napus L.) and near the garden with $P$. rapae host plants, Brassica oleracea L. (FrIBERG et al., 2015). Pieris rapae is often found in cultivated Brassica fields (FrIBERG et al., 2015); in the study area such fields are usually treated with pesticides two-three times a year, which constitues a threat for their population. An individual from a moth species from the family Erebidae, Polypogon tentacularia, was photographed while sitting on a leaf of Zea maysL., near fallow land inhabited by the $P$. tentacularia host plant from the genus Solidago, Solidago canadensis L. (Koren et al., 2015), while Autographa gamma was photographed on the leaf of Sorghum halepense (L.) Pers. Although the study area includes some parcels with intensive agriculture, some parcels sown with Triticum aestivum L. are not treated with herbicides and pesticides' and so create a habitat for Matricaria sp. inside the crop field and Urtica dioica L. on its edges, which are host plants of Macdunnoughia confusa, found near the light (Koren et al., 2015).

Gardens in the study area attracted some species like Macroglossum stellatarum, photographed on a flower of Zinnia elegans Jacq. Besides vegetables and flowers, gardens in the study area also contain plant species like Chenopodium albumL., Rumex sp., genus Polygonum, Trachea atriplicis caterpillar food plants (Koren \& Gомвос, 2017). Mentioned moth species was found on a wall below the house outside light. As in some gardens, mostly those planted with vegetables, pesticides and herbicides are used, the larvae of butterflies and moths as well as adult species could be affected.

As orchards and backyards are usually planted with indigenous fruit cultivars, which mostly do not demand treatment with pesticides, many butterfly and moth species were found there. Celastrina argiolus and Brenthis daphne were photographed on the leaf of Rubus idaeus L., planted between a small meadow and a garden. Apatura ilia was found sitting on gloves on a house terrace and while flying along the forest edge. Also, this species occurred on the leaf of Pyrus communis 'Williams' in a backyard with fruit trees and livestock dung, probably attracted by the honey dew and dung that it uses for food (ŠAšić et al., 2015). Polygonia c-album was photographed while sitting on the leaves of Rubus idaeus L. and on a branch of Prunus domestica L., while Araschnia levana was found on 
the leaves of Rubus idaeus L. A young tree of Prunus domestica L., in the backyard, attracted Pararge aegeria. Cydia pomonella, common in old extensive orchards and gardens with lower impacts of pesticides (KoREN \& Gомвос, 2017), was found on the leaf of a plant species from the genus Malus. Fruits of this genus as well as of Prunus domestica L., Prunus persica (L.) Batsch, genus Pyrus, Juglans, Cydonia, all present in orchards and backyards of the study area, are all used by C. pomonella larvae for feeding (KoREN \& Goмвoc, 2017). Diasemia reticularis was found sitting on the leaf of Rubus idaeus L., which grows between an orchard and garden. The study area is rich in bark lichens on branches of the trees in orchards, backyards and forests, forage for the overwintering larvae of Laspeyria flexula (MACDONALD \& Feber, 2015), found near the light.

The forest edge presents an important habitat for different species. Issoria lathonia was found sitting on the leaf of Corylus avellana L. while Papilio machaon was found during its flight from the forest to the area of backyards and orchards, where it was also observed. The area where this species was found is rich in plants from the family Apiaceae like Daucus carota L. ssp. carota, Petroselinum crispum (Mill.) A. W. Hill, Foeniculum vulgare Mill., some of P. machaon host plants (Trappe et al., 2017). Many butterfly species are not camera shy and they can be fully contained within the camera's field (QuinN \& KLYM, 2009). However, some butterfly species move rapidly like the genus Colias, Hesperiidae genera like Spialia and Pyrgus, so it is not easy to record them with digital photography (Koren \& Letić, 2014). P. machaon belongs to the group of the best flyers among butterflies (ŠAšrć et al., 2015) and it was quite tough to photograph specimens of them in the field, so the video was taken and then observed and transformed into photographs for identification. The genus Quercus occurs on the forest edge in the study area, while the genus Salix inhabits the stream below the forest slopes (Macaria alternata and Lomographa temerata host plants) as well as Alnus (in the part between the forest and the pond), another host plant of Macaria alternata (WARING et al., 2003; Koren et al., 2015), so their occurrence near a house light in this study reflects the existence of their preferred habitats. Perizoma alchemillata was found near the exterior house light, close to the forest edge where $P$. alchemillata host plants from the family Lamiaceae and Galeopsis sp. (Gathmann et al., 2006) grow. One of the Polypogon tentacularia host plants, Solidago canadensis L., inhabits the slope between the forest and meadow, while plants from the genus Hieracium, and Taraxacum officinale Weber, also P. tentacularia host plants (Koren et al., 2015) inhabit meadow near the slope. The main threats for forest edges is presented by the mowing of lower plants and shrubs for the sake of the maintenance of agricultural land and meadows, which usually almost reach the forest edges.

Forests in and around the study area are deciduous, containing species of the genera Quercus, Carpinus, Fagus, Acer but also from the genera Alnus and Salix in the lower parts of the terrain, closer to the pond and stream which stretches alongside the forest in the study area. Apoda limacodes, the only representative of the family Limacodidae found in this study, was photographed on the wall beyond the exterior house light and caterpillars of this species feed on the leaves 
of tree species of Quercus, Carpinus, Fagus and Acer (Konen \& Goмвос, 2017). Another species attracted to the light is Endotricha flammealis and caterpillars of this species feed on plants from the genus Quercus, present in the deciduous forest within the surveyed area, plants from the genus Salix, inhabiting the stream, which stretches along this forest as well as on plants from the genus Lotus (KoreN \& Gомвос, 2017), on the meadow in the study area. Larvae of the adult Selenia lunularia, found in a backyard inhabited by the S. lunularia host plant, Prunus sp., also can use Quercus sp. from the deciduous forest in the study area, as a host plant (Koren et al., 2015). Some of the host plants of the Idaea rusticata, found near the house light, are Clematis vitalba L., which inhabits the forest in the study area where it hangs from the trees more exposed to light, and Hedera helix L. (WARING et al., 2003), present both in forests and backyards in the study area. Adult Lomaspilis marginata was found near the house light close to the stream in the study area, inhabited with host plant of this species, Salix sp. (WARING et al., 2003), while another host plant of L. marginata, Populus nigra L., grows near the road along the edge of the study area (Noble, 1975). Melanchra persicariae, found near the light, uses a lot of different host plants from Urtica dioica L., Convolvulus arvensis L., Corylus avellana L. (WARING et al., 2003), Sambucus nigra L. (Noble, 1975) to Larix decidua Mill., from the family Pinaceaea (НеAтн \& Еммет, 1979). Although not included in the surveyed area, forest of Larix decidua Mill. is in the close vicinity of the study area and constitutes a preferred habitat for this species, together with the mentioned plant species. Forests in the study area are still quite well maintained but, nowadays, many forest parts in the near surrounding of the study area and even wider Bjelovar-Bilogora area are destroyed because of clearcut logging, bad management and absence of proper afforestation. On such woodland areas, invasive plant species like Robinia pseudoacacia L. become dominant. Moreover, new boreholes are opened in some forests near the study area and the light they emit during the night probably affects the physiological characteristics of the forest trees. More research should be conducted in order to gain better understanding how the mentioned threats affect host plants as well as butterfly and moth biodiversity and survival.

The results of this research have a preliminary character so they should be a starting point for further research. Surveys of the butterfly and moth fauna of Bjelovar-Bilogora are needed to gain more recent knowledge about their biodiversity and the stability of their populations under different threats, especially for butterflies, such as agricultural intensification, abandonment of traditional agriculture, climate change (including droughts), change of woodland management (VAN SWAAY, 2010), oil boreholes and seismic investigation of oil and gas reserves.

\section{ACKNOWLEDGEMENTS}

I would like to thank to Dr. Toni Koren (Hyla Association, Zagreb) for revision of butterfly and moth identification in this study. 


\section{REFERENCES}

Basset, Y., Novotny, V., Miller, S. E. \& Pyle, R., 2000: Quantifying Biodiversity: Experience with Parataxonomists and Digital Photography in Papua New Guinea and Guyana. BioScience 50(10), 899-908.

DoмAC, R., 2002: Croatian flora, Manual for plant determination. Školska knjiga, Zagreb. 504 pp.

Fibiger, M., 1993: Noctuinae II. Noctuidae Europaeae. Volume 2. Entomological Press, Soros. 230 pp.

FIŠTREK, Ž., 2018: Butterfly fauna (Insecta, Lepidoptera, Papilionoidea) of northern Moslavina (Croatia). Natura Croatica 27(1), 97-109.

FriberG, M., Posledovich, D. \& WikLund, C., 2015: Decoupling of female host plant preference and offspring performance in relative specialist and generalist butterflies.Oecologia 178(4), 1181-1192.

Gathmann, A., Wirooks, L., Eckert, J. \& Schuphan, I., 2006: Spatial distribution of Aglais urticae (L.) and its host plant Urtica dioica (L.) in an agricultural landscape: implications for Bt maize risk assessment and post-market monitoring. Environmental Biosafety Research 5, 27-36.

Grubišić, D., Igrc Barčić, J., Barić, B. \& Gotlin ČulJaK, T., 2006: Possibilities for biological control of velvetleaf (Abutilon theophrasti Medik.) with phytophagous insects. Entomologia Croatica 10(1-2), 67-86.

Gutiérrez, D., León-Cortés, J. L., Menéndez, R., Wilson, R. J., Cowley, M. J. R. \& Thomas, C. D., 2001: Metapopulations of Four Lepidopteran Herbivores on a Single Host Plant, Lotus corniculatus. Ecology 82(5), 1371-1386.

Hajibabaei, M., Janzen, D. H., Burns, J. M., Hallwachs, W. \& Hebert, P. D. N., 2006: DNA barcodes distinguish species of tropical Lepidoptera. Proceedings of the National Academy of Sciences 103(4), 968-971.

Heath, J. \& Емmет, A. M. (eds), 1979: The Moths and Butterflies of Great Britain and Ireland. Volume 9 (Sphingidae - Noctuidae Noctuinae and Hadeninae). Curwen Books. 288 pp.

JANZ, N., Bergström, A. \& SJögren, A., 2005: The role of nectar sources for oviposition decisions of the common blue butterfly Polyommatus icarus. Oikos 109, 535-538.

Jin, Q., Hu, X.-M., Han, H.-L., Chen, F., CaI, W.-J., Ruan, Q.-Q., Liv, B., Luo, G.-J., Wang, H., Liu, X., WARD, R. D., WU, C.-S., WILsOn, J.-J. \& ZHANG, A.-B., 2018: A two-step DNA barcoding approach for delimiting moth species: moths of Dongling Mountain (Beijing, China) as a case study. Scientific Reports 8, 14256. DOI:10.1038/s41598-018-32123-9

Koren, T. \& Letić, G., 2014: Butterfly fauna (Lepidoptera: Rhopalocera) of Donji Emovci, Požega, Croatia. Natura Sloveniae 16(2), 5-16.

Koren, T., Vuкотіс́, K. \& Črne, M., 2015: Diversity of the moth fauna (Lepidoptera: Heterocera) of a wetland forest: A case study from Motovun forest, Istria, Croatia. Periodicum biologorum 117(3), 399-414.

Koren, T. \& Gomboc, S., 2017: Moths of Krapina- Zagorje County. Public institution for the management of protected areas of the nature of the Krapina-Zagorje County, Printera group, Zagreb. 373 pp.

Koren, T., Zadravec, M. \& LaUš, B., 2017: On the discovery of Arytrura musculus (Ménétriés, 1859) (Lepidoptera: Erebidae) in Croatia.Periodicum Biologorum 119(4), 295-298.

Koren, T., 2018: Diversity of moths (Lepidoptera: Heterocera) in the surroundings of the Bednja River, Varaždin County, Northern Croatia. Natura Croatica 27(1), 111-141.

Kučinić, M. \& Plavac, I., 2009: Butterflies. Manual for inventarisation and condition monitoringi. State Institute for Nature Protection. Zagreb. 43 pp.

Kučinić, M., Matešić, M., Koren, T., Mrnjavčić Vojvoda, A., Vajdić, M., Pelić, D. F., Bukvić, V. \& Perović, F., 2014: First check list of the subfamily Arctiinae (Lepidoptera, Erebidae) in Croatia, with the finding of Rhyparioides metelkana (Lederer, 1861), new species in Croatian fauna from the valley of the Neretva River. Natura Croatica 23(1), 67-87.

Lafranchis, T., 2004: Butterflies of Europe. New Field Guide and Key. Diatheo, Paris. 351 pp.

Leraut, P., 2009: Moths of Europe, Volume 2: Geometrid Moths. NAP Editions, Verrières-le Buisson. 808 pp.

Leraut, P., 2014: Moths of Europe, Volume 4: Pyralids 2. NAP Editions, Verrières-le Buisson. 440 pp.

Macdonald, D. W. \& Feber, R. E., 2015: Wildlife Conservation on Farmland: Managing for Nature on Lowland Farms. Oxford University Press. 336 pp.

Manley, C., 2008: British moths and butterflies. A\&C Black Publishers, London. 352 pp. 
Medhi, J., Barman, J. \& Sharma, S., 2018: Assessment on butterfly and its diversity in Tegheria (Waterfall), Dimoria development Block, Kamrup (M) district of Assam, India. Journal of Entomology and Zoology Studies 6(3), 1746-1750.

Mihoci, I., Delić, A., Guurašin, B., Bučar, M. \& Kučinić, M., 2007: First finding of the critically endangered butterfly Maculinea alcon (Denis \& Schiffermüller, 1775) (Lepidoptera: Lycaenidae) in the Pannonian part of Croatia. Natura Croatica 16(1), 19-28.

Mrnjavčić Vojvoda, A., Minoci, I., Vajdić, M. \& Kučinić, M., 2014: Antitype suda (Geyer, 1832) (Lepidoptera: Noctuidae), new species of noctuid fauna of Croatia, found in the Biokovo Nature Park. Natura Croatica, 23(2), 379-388.

Nikolić, T. (ed.), 2018: Flora Croatica Database. On-Line (http://hirc.botanic.hr/fcd). Department of Botany and Botanical Garden, Faculty of Science, University of Zagreb, Zagreb. Date of access 15/11/2018.

Noble, K., 1975: The Natural foodplants of Macrolepidoptera larvae in Britain, Part II. Unpublished Report. Field Studies Council, Preston Montford, UK.

NowAcki, J., 1998: The Noctuids (Lepidoptera, Noctuidae) of Central Europe. Coronet Books, Bratislava. $51 \mathrm{pp}$.

Patterson, B., 2012: Moth Photographers Group. A walk through the moth families - Getting started with moths Retrieved from http://mothphotographersgroup.msstate.edu/WalkThroughIndex. shtml on 27 November 2018.

PolJAK, Ž., 2001: Hrvatske planine. Golden marketing, Zagreb.

Prudic, K. L., Mcfarland, K. P., Oliver, J. C., Hutchinson, R. A., Long, E. C., Kerr, J. T. \& Larrivée, M., 2017: eButterfly: Leveraging Massive Online Citizen Science for Butterfly Conservation. Insects 8(2), 53. doi:10.3390/insects8020053

Quinn, M. \& KLym, M., 2009: An Introduction to Butterfly Watching. Texas Parks and Wildlife, Texas. 41 pp.

Remboski, T. B., De Souza, W. D., De Aguiar, M. S. \& Ferreira Jr, P. R., 2018: Identification of Fruit Fly in Intelligent Traps Using Techniques of Digital Image Processing and Machine Learning. In SAC 2018: SAC 2018: Symposium on Applied Computing , April 9-13, 2018, Pau, France. ACM, NewYork, NY, USA, 8 pages. https://doi.org/10.1145/3167132.3167155

Rice, A. J. \& White, P. J. T., 2015: Community patterns in urban moth assemblages. Journal of the Lepidopterists' Society 69(3), 149-156.

Rosenthal, S. S., Clement, S. L., Hostettler, N. \& Mimmocchi, T., 1988: Biology of Tyta luctuosa [Lep. : Noctuidae] and its potential value as a biological control agent for the weed Convolvulus arvensis. Entomophaga 33(2), 185-192.

Sourakov, A., 2018: Mass aggregations of Idia moths (Lepidoptera: Erebidae) inside hollow trees in Florida. Tropical Lepidoptera Research 28(1), 35-38.

Suetsugu, K. \& Hayamizu, M., 2014: Moth floral visitors of the three rewarding Platanthera orchids revealed by interval photography with a digital camera. Journal of Natural History 48(17-18), 1103-1109.

ŠAšić, M. \& Minoci, I., 2011: Annotated checklist of Croatian butterflies with vernacular names. Natura Croatica 20(2), 425-436.

ŠAšić, M., Minoci, I. \& KučInIĆ, M., 2015: Red Book of Butterflies of Croatia. Ministry of Environmental and Nature Protection, State Institute for Nature Protection, Croatian Natural History Museum, Zagreb. $180 \mathrm{pp}$.

Tolman, T. \& Lewington, R., 2008: Butterflies of Britain \& Europe. Harper Collins Publishers, London. 384 pp.

Tóth, P., Tóthová, M. \& CAgáŇ, L., 2004: Are there important natural enemies of field bindweed within Slovakian Noctuidae species? Acta fytotechnica et zootechnica, Vol. 7, Special Number, Proceedings of the XVI. Slovak and Czech Plant Protection Conference organised at Slovak Agricultural University in Nitra, Slovakia.

Tóth, J. P., Bereczki, J., Végvári, Z., Juhász, E. \& VArga, Z., 2015: Different host plant utilization ability of two closely related Melitaea species (Lepidoptera: Nymphalidae). European Journal of Entomology 112(1), 120-125.

Trappe, J., Kunz, F., Weking, S. \& Kamp, J., 2017: Grassland butterfly communities of the Western Siberian forest steppe in the light of post-Soviet land abandonment. Journal of Insect Conservation 21, 813-826. 
Van Nieukerken, E. J., Kaila, L., Kitching, I. J., Kristensen, N. P., Lees, D. C., Minet, J., Mitter, C., Mutanen, M., Regier, J. C., Simonsen, T. J., Wahlberg, N., Yen, S.-H., Zahiri, R., Adamski, D., Baixeras, J., Bartsch, D., Bengtsson, B. Å., Brown, J. W., Bucheli, S. R., Davis, D. R., De Prins, J., De Prins, W., Epstein, M. E., Gentili-Poole, P., Gielis, C., Hättenschwiler, P., Hausmann, A., Holloway, J. D., Kallies, A., Karsholt, O., Kawahara, A. Y., Koster, S., Kozlov, M., Lafontaine, J. D., Lamas, G., Landry, J., Lee, S., Nuss, M., Park, K.-T., Penz, C., Rota, J., Schintlmeister, A., Schmidt, B. C., Sohn, J.-C., Solis, M. A., Tarmann, G. M., Warren, A. D., Weller, S., Yakovlev, R. V., Zolotuhin, V. V. \& Zwick, A., 2011: Order Lepidoptera Linnaeus, 1758. In ZhanG, Z-Q. (Ed.): Animal Biodiversity: An outline of higher-level classification and survey of taxonomic richness. Auckland, New Zealand: Magnolia Press. Zootaxa 3148, 212-221.

Van Swaay, C., Cuttelod, A., Collins, S., Maes, D., Lopez Munguira, M., Šašić, M., Settele, J., Verovinik, R., Verstrael, T., Warren, M., Wiemers, M. \& Wynhof, I., 2010: European Red List of Butterflies. Publications Office of the European Union, Luxembourg. $60 \mathrm{pp}$.

Wallis De Vries, M. F., Van Swaay, C. A. M. \& Plate, C. L., 2012: Changes in nectar supply: A possible cause of widespread butterfly decline. Current Zoology 58(3), 384-391.

Waring, P., Townsend, M. \& Lewington, R., 2003: Field Guide to the Moths of Great Britain and Ireland, 1st ed. British Wildlife Publishing, Hook, UK

Winterton, S. L., Guek, H. P. \& Brooks, S. J., 2012: A charismatic new species of green lacewing discovered in Malaysia (Neuroptera, Chrysopidae): the confluence of citizen scientist, online image database and cybertaxonomy. ZooKeys 214, 1-11.

www.bbz.hr/bjelovarsko-bilogorska-zupanija/detaljnije/zemljopisni-polozaj.htm.

Downloaded 28 March 2018

www.lepiforum.de

www.mothphotographersgroup.msstate.edu/WalkThroughIndex.shtml

Tab. 1. Systematic list of butterfly and moth species found in Gornje Plavnice (Bjelovar) with observation dates.

\begin{tabular}{ll} 
Species & Observation date in 2017 \\
Fam. Tortricidae: & \\
\hline 1. Agapeta zoegana (Linnaeus, 1767) & $11.8 ., 19.8 .2017$ \\
2. Celypha striana ([Denis \& Schiffermüller], 1775) & 31.7 .2017 \\
3. Grapholita compositella (Fabricius, 1775) & 13.8 .2017 \\
4. Cydia pomonella (Linnaeus, 1758) & 24.7 .2017 \\
\hline Fam. Limacodidae: & \\
\hline 5. Apoda limacodes (Hufnagel, 1766) & 21.7 .2017 \\
\hline Fam. Papilionidae: & \\
\hline 6. Iphiclides podalirius (Linnaeus, 1758) & 1.7 .2017 \\
\hline 7. Papilio machaon (Linnaeus, 1758) & 11.8 .2017 \\
\hline Fam. Hesperiidae: & \\
\hline 8. Erynnis tages (Linnaeus, 1758) & 4.7 .2017 \\
9. Carcharodus alceae (Esper, 1780) & $16.7 ., 29.7 .2017$ \\
10. Pyrgus malvae (Linnaeus, 1758) & 27.4 .2017 \\
11. Pyrgus armoricanus (Oberthür, 1910) & 19.7 .2017 \\
12. Thymelicus lineola (Ochsenheimer, 1808) & 22.6 .2017 \\
13. Thymelicus sylvestris (Poda, 1761) & 4.6 .2017 \\
14. Ochlodes sylvanus (Esper, 1777) & 28.7 .2017 \\
\hline Fam. Pieridae: & \\
\hline 15. Pieris rapae (Linnaeus, 1758) & $24.6 ., 3.8 ., 8.8 ., 15.8 ., 23.8 .2017$ \\
16. Pieris napi (Linnaeus, 1758) & $26.6 ., 8.7 .2017$ \\
17. Colias crocea (Geoffroy, 1785) & 3.8 .2017 \\
\hline
\end{tabular}




\begin{tabular}{|c|c|}
\hline \multicolumn{2}{|l|}{ Fam. Lycaenidae: } \\
\hline 18. Lycaena phlaeas (Linnaeus, 1761) & 1.7., 8.7., 18.7., 8.8.2017 \\
\hline 19. Lycaena dispar (Haworth, 1802) & 6.6., 13.8 .2017 \\
\hline 20. Lycaena tityrus (Poda, 1761) & 17.7., 28.7., 29.7., 31.7.2017 \\
\hline 21. Cupido argiades (Pallas, 1771) & 15.7., 22.7., 8.8.2017 \\
\hline 22. Cupido alcetas (Hoffmannsegg, 1804) & 27.4.2017 \\
\hline 23. Celastrina argiolus (Linnaeus, 1758) & 1.7.2017 \\
\hline 24. Cyaniris semiargus (Rottemburg, 1775) & 17.7.2017 \\
\hline 25. Polyommatus icarus (Rottemburg, 1775) & 27.6., 1.7., 4.7., 8.7., 16.7., 8.8.2017 \\
\hline \multicolumn{2}{|l|}{ Fam. Nymphalidae: } \\
\hline 26. Pararge aegeria (Linnaeus, 1758) & 14.4., 26.6.2017 \\
\hline 27. Lasiommata megera (Linnaeus, 1767) & 4.7., 15.7 .2017 \\
\hline 28. Coenonympha glycerion (Borkhausen, 1788) & 16.7., 19.7., 28.7., 29.7.2017 \\
\hline 29. Coenonympha pamphilus (Linnaeus, 1758) & $\begin{array}{l}\text { 27.4., 30.4., 30.6., 8.7., 16.7., 25.7. } \\
\text { 27.7.2017 }\end{array}$ \\
\hline 30. Maniola jurtina (Linnaeus, 1758) & 24.6., 26.6., 1.7., 8.7., 21.7., 8.8. 2017 \\
\hline 31. Melanargia galathea (Linnaeus, 1758) & 19.6., 24.6., 26.6., 6.7.2017 \\
\hline 32. Issoria lathonia (Linnaeus, 1758) & 29.7.2017 \\
\hline 33. Brenthis daphne (Bergsträsser, 1780) & 26.6.2017 \\
\hline 34. Neptis sappho (Pallas, 1771) & 26.7.2017 \\
\hline 35. Apatura ilia ([Denis \& Schiffermüller], 1775) & 19.7., 4.8., 8.8.2017 \\
\hline 36. Aglais io (Linnaeus, 1758) & 17.4., 18.6.2017 \\
\hline 37. Vanessa atalanta (Linnaeus, 1758) & 15.8.2017 \\
\hline 38. Polygonia c-album (Linnaeus, 1758) & 6.7., 8.7., 12.7., 26.7.2017 \\
\hline 39. Araschnia levana (Linnaeus, 1758) & 17.4., 21.7., 24.7., 28.7., 31.7.2017 \\
\hline 40. Melitaea phoebe ([Denis \& Schiffermüller], 1775) & 20.7., 21.7., 25.7.2017 \\
\hline 41. Melitaea athalia (Rottemburg, 1775) & 27.4., 1.5., 26.6., 16.7., 27.7., 28.7.2017 \\
\hline \multicolumn{2}{|l|}{ Fam. Pyralidae: } \\
\hline 42. Synaphe punctalis (Fabricius, 1775) & 17.7.2017 \\
\hline 43. Endotricha flammealis ([Denis \& Schiffermüller], 1775) & 17.7., 21.7.2017 \\
\hline 44. Oncocera semirubella (Scopoli, 1763) & 16.7.2017 \\
\hline 45. Homoeosoma sinuella (Fabricius, 1794) & 13.7., 3.8.2017 \\
\hline \multicolumn{2}{|l|}{ Fam. Crambidae: } \\
\hline 46. Elophila nymphaeata (Linnaeus, 1758) & 21.7.2017 \\
\hline 47. Pyrausta purpuralis (Linnaeus, 1758) & 26.7., 31.7.2017 \\
\hline 48. Sitochroa verticalis (Linnaeus, 1758) & 29.7.2017 \\
\hline 49. Ostrinia nubilalis (Hübner, 1796) & 23.7., 28.7., 6.8.2017 \\
\hline 50. Pleuroptya ruralis (Scopoli, 1763) & 17.7., 18.7.2017 \\
\hline 51. Diasemia reticularis (Linnaeus, 1761 ) & 1.7.2017 \\
\hline 52. Nomophila noctuella ([Denis \& Schiffermüller], 1775) & 22.6., 21.7.2017 \\
\hline
\end{tabular}

$\begin{array}{ll}\text { Fam. Sphingidae: } & \\ \text { 53. Macroglossum stellatarum (Linnaeus, 1758) } & 16.7 .2017 \\ \text { 54. Deilephila porcellus (Linnaeus, 1758) } & 3.8 .2017\end{array}$

$\begin{array}{ll}\text { Fam. Geometridae: } & \\ \text { 55. Lomaspilis marginata (Linnaeus, 1758) } & 23.7 .2017 \\ \text { 56. Macaria alternata ([Denis \& Schiffermüller], 1775) } & 15.7 .2017 \\ \text { 57. Chiasmia clathrata (Linnaeus, 1758) } & 27.4 .2017 \\ \text { 58. Selenia lunularia (Hübner, 1788) } & 22.6 .2017 \\ \text { 59. Lomographa temerata ([Denis \& Schiffermüller], 1775) } & 23.7 .2017 \\ \text { 60. Campaea margaritaria (Linnaeus, 1761) } & 31.8 .2017 \\ \text { 61. Ematurga atomaria (Linnaeus, 1758) } & 17.4 ., 16.7 ., 6.8 .2017 \\ \text { 62. Chlorissa cloraria (Hübner, 1813) } & 24.8 .2017\end{array}$




\section{Fam. Geometridae:}

63. Idaea ochrata (Scopoli, 1763)

8.7.2017

64. Idaea rusticata ([Denis \& Schiffermüller], 1775)

25.7.2017

65. Idaea dimidiata (Hufnagel, 1767)

4.8.2017

66. Idaea aversata (Linnaeus, 1758)

1.9.2017

67. Idaea degeneraria (Hübner, 1799)

20.7.2017

68. Scopula immorata (Linnaeus, 1758)

8.7.2017

69. Scopula virgulata ([Denis \& Schiffermüller], 1775)

29.7.2017

70. Scopula ornata (Scopoli, 1763)

24.8.2017

71. Timandra comae (Schmidt, 1931)

13.7., 21.7.2017

72. Cyclophora annularia (Fabricius, 1775)

4.8.2017

73. Xanthorhoe ferrugata (Clerck, 1759)

25.8.2017

74. Catarhoe cuculata (Hufnagel, 1767)

23.7., 11.8 .2017

75. Camptogramma bilineata (Linnaeus, 1758)

$25.8,26.8 .2017$

76. Pelurga comitata (Linnaeus, 1758)

19.8.2017

77. Perizoma alchemillata (Linnaeus, 1758)

18.7.,11.8.2017

\section{Fam. Notodontidae:}

78. Clostera pigra (Hufnagel, 1766)

24.8.2017

\section{Fam. Erebidae:}

79. Phragmatobia fuliginosa (Linnaeus, 1758)

19.8.2017

80. Rhyparia purpurata (Linnaeus, 1758)

4.6.2017

81. Polypogon tentacularia (Linnaeus, 1758)

16.7., 20.7.2017

82. Laspeyria flexula ([Denis \& Schiffermüller], 1775)

1.9.2017

83. Euclidia glyphica (Linnaeus, 1758)

18.5.2017

\section{Fam. Noctuidae:}

84. Macdunnoughia confusa (Stephens, 1850)

24.8.2017

85. Autographa gamma (Linnaeus, 1758)

26.6., 27.7.2017

86. Deltote bankiana (Fabricius, 1775)

1.5., 13.7.2017

87. Acontia trabealis (Scopoli, 1763)

27.4., 1.5., 1.7., 18.7.2017.

88. Acontia lucida (Hufnagel, 1766)

6.7.2017

89. Aedia funesta (Esper, 1786)

30.6., 10.7.2017

90. Tyta luctuosa ([Denis \& Schiffermüller], 1775)

16.7.2017

91. Heliothis viriplaca (Hufnagel, 1766)

28.7.2017

92. Nyctobrya muralis (Forster, 1771)

17.8.2017

93. Pseudeustrotia candidula ([Denis \& Schiffermüller], 1775)

16.7.2017

94. Hoplodrina ambigua ([Denis \& Schiffermüller], 1775)

19.8.2017

95. Trachea atriplicis (Linnaeus, 1758)

10.7.2017

96. Melanchra persicariae (Linnaeus, 1761)

23.7.2017

97. Conisania luteago ([Denis \& Schiffermüller], 1775)

6.7.2017

98. Agrotis exclamationis (Linnaeus, 1758)

15.7., 16.7., 21.7.2017

99. Axylia putris (Linnaeus, 1761)

18.7.2017

100. Xestia c-nigrum (Linnaeus, 1758)

23.7.2017 